\title{
Non-invasive Evaluation of Neonatal Cerebral Status in the Newborns of Mothers Addicted to Alcohol and Drugs
}

\author{
DRAGOS VALENTIN CRAUCIUC ${ }^{1}$, EDUARD GABRIEL CRAUCIUC ${ }^{1 *}$, CATALIN J IOV2*, CRISTINA FURNICA ${ }^{1 *}$, TATIANA IOV ${ }^{3}$ \\ ${ }^{1}$ Grigore T. Popa University of Medicine and Pharmacy, 16 Universitatii Str., 700115, Iasi, Romania \\ ${ }^{2}$ APOLLONIA University of Iasi, Romania, TRIAS Microelectronics,17 Nicolina Alley, 700221, lasi, Romania \\ ${ }^{3}$ Institute of Forensic Medicine,4 Buna Vestire Str.,700455, Iasi, Romania
}

The present study aims to assess the effects of alcohol and drug consumption on the cerebral status of a newborn with risk. Although there is a vast literature on the quality of life in terms of health, there is no uniform point of view, since the well-being of a person implies other elements that consider not only health butalso the economic and educational environment in which the individual evolves and often these factors are connected. Besides, there is no valid instrument for measuring the quality of life either for an adult or for a child. In most cases, alcohol consumption intensifies in time, significantly decresing the quality of life for the mother and especially for the conception product. The study focuses on showing the The study focuses on highlighting the psychosocial and pharmacological aspects relevant to the diagnosis and management of neonatal cerebral status. The study participants, whose responses were the base for the quantitative analyzes, were individually interviewed using a standardized interview protocol. The interviews were conducted between October 2015 and September 2017. The interview protocol included three sections, in this chapter focusing our attention on the following sections: a) socio-demographic characteristics: age of gestation, sex of the newborn; b) clinical data: Presentation, Weight at Birth, Apgar Score, Cerebral Saturation (rSO ), Peripheral saturation ( $\mathrm{SpO}_{2}$ ), The extraction fraction (FTOE), Parameters harvested from the umbilical cord at birth ( $\mathrm{pH}$, Base excess ( $\left.\mathrm{BE}), \mathrm{pCO}_{2}, \mathrm{pO}, \mathrm{MetHb}, \mathrm{COHb}\right), \mathrm{c}$ ) risk profile: mother's alcohol consumption, including during pregnancy and drug use. The study group consisted of 90 infants born full term in Elena Doamna Maternity Hospital in lasi, between 2015-2017, included in the programme of follow-up of the newborn with risk with the purpose of performing an non-invasive assessment of the fetal and neonatal cerebral status, in order to prevent and establish treatmentmethods for perinatal asphyxia. Based on the information obtained through the preliminary documentation, 30 newborns with alcohol and / or drug-consuming mothers and 60 neonates with risk-free mothers were selected - the control batch, who accepted to participate in the study. The cases studied showed the homogeneity of the groups depending on the mother's age and gestational age, as well as the sex of the newborn and the weight at birth $(p>0.05)$. In neonates from mothers at risk, the underreference level of 1-minute brain saturation, combined with a lower gestational age and the $62.5 \%$ probability of performing a caesarean section at low levels of cerebral saturation was noted in $66.7 \%$ of newborns. The cut off value of $\mathrm{SpO}_{2}$, was established at $70 \mathrm{~mL} / 100 \mathrm{~g} / 1 \mathrm{~min}$, with a sensitivity of $50.9 \%$ and a specificity of $51.3 \%$, after reading the coordinates of ROC curve, but the prediction was not significant from the statistical point of view $(p=0.670)$. The mean level of base excess was al excesului de baze was slightly lower in newborns with the extraction fraction below the cut off value (-4.64 vs $-4.18 ; p=0.560)$. According to the cases studied, 1 min after birth, 23.3\% of the newborns showed an increased level of $p \mathrm{CO}_{2}$ associated with a reduced level of peripheral saturation $(r=-0.231 ; p=0.05)$. The correlation between the $p 0$, level and the cerebral saturation, recorded 1 min after birth, was direct, but reduced as intensity $(r=+0.295 ; p=0.049)$. About $27 \%$ of the newborns associated increased values of $\mathrm{pO}$, with reduced values of the extraction fraction $(r=-0.272 ; p=0.047)$. The newborns with an extraction fraction over the cut off value had a level of $\mathrm{COH} b$ below $1 \%(p=0.756)$ more frequently. Newborns from mothers who have consumed alcohol and/ordrugs, including during pregnancy, show a reduced level of cerebral saturation and peripheral saturation 1 minute after birth. In 16.7\% of new borns, the extraction limit was below the baseline 1 minute after birth.

Keywords: newborn, alcohol, drugs, cerebral status

Although there is a vast literature on the quality of life in terms of health, there is no uniform view, since the wellbeing of a person involves other elements not only of health but also of the economic and educational environment in which the individual evolves, and often these factors are mixed [1-4]. Besides, there is no valid instrument for measuring the quality of life either for an adult or for a child. In most cases, alcohol consumption intensifies in time, significantly decresing the quality of life for the mother and especially for the conception product [5-8].

\section{Experimental part}

Material and method

Study group. The study group was made of 90 newborns at term in Elena Doamna Maternity lasi, during 2015 and 2017, who were included in the programme of follow-up of the newborn at risk for a non-invasive assessment of the fetal and neonatal cerebral status, with the purpose of preventing and establishing the treatment methods in case of perinatal asphyxia.

The sample size $(n=90)$ at the significance threshold of $95 \%$ w ith a sampling error of $\pm 6 \%$ is representative for

*email:crauciuc@yahoo.com; iovcatalin@yahoo.com; cristinafurnica@yahoo.com 
the population of lasi city (Romania's Statistical Yearbook, http://www.insse.ro/cms/ro/tags/anuarul-statistic-alromaniei).

Inclusion criteria: Age of gestation at birth with variations between 37 and 42 weeks; the mother's age over 18; the mother's free consent to respond to the questionnaire.

Depending on the mother's alcohol consumption, including during pregnancy and / or drug use, the study group was divided into two batches:

- Lot I - 30 newborns with mothers that declare alcohol consumption and / or drug use, even occasionally, including during pregnancy;

- Lot II - 60 newborns with mothers who deny alcohol consumption and / or drug use.

The cerebral status is assessed only clinically in the delivery room with subjective variations based on the neonatal behaviour, muscle tone and reflexes. Thus, it is beneficial to know objectively the neonatal brain activity immediately after birth. For this purpose there are three measurable brain parameters by three non-invasive, immediate, real-time assessment methods: cerebral blood flow measured by transfontalian ultrasonography, cerebral electrical activity evaluated with integrated amplitude EEG and cerebral tissue oxygenation measured by near infrared light spectroscopy (NIRS) $[3,9,10]$.

\section{Statistical methods}

The study was prospective and was conducted by applying questionnaires to which mothers responded, after being informed that they are participating in an epidemiological study, between October 2015 and September 2017. The interview protocol included three sections, in this chapter focusing our attention on the following sections: a) socio-demographic characteristics: age of gestation, gender of the newborn; b) clinical data: Presentation, Weight at Birth, Apgar Score, Cerebral Saturation $\left(\mathrm{rSO}_{2}\right)$, Peripheral saturation $\left(\mathrm{SpO}_{2}\right)$, The extraction fraction (FTOE), Parameters harvested from the umbilical cord at birth ( $\mathrm{pH}$, Base excess (BE), $\mathrm{pCO}_{2}, \mathrm{pO}_{2^{\prime}}$ MetHb, $\mathrm{COHb}$ ), c) risk profile: mother's alcohol consumption, including during pregnancy and drug use [1114].

The data has been systematized and centralized into a SPSS 18.0 database. The descriptive statistical analysis, at the $95 \%$ significance threshold, investigated the normality of the value series to determine the statistical functions to which they fit. The statistical analysis consisted in applying qualitative significance tests $\left(\chi^{2}\right.$ test, Pearson correlation test) and quantitative significance tests ( $\mathrm{t}$-Student test, $\mathrm{F}$ test).

\section{Results and discussions}

Based on the cases studied we noticed the homogeneity of batches according to the mother's age (25.87 vs 27.60 years old; $p=0.113$ ) and the gestational age ( 38.43 vs 38.65 weeks; $p=0.309$ ) (table 1), but also according to the newborn gender and his/her weight at birth (fig. 1).

Newborn gender $(p=0,082)$
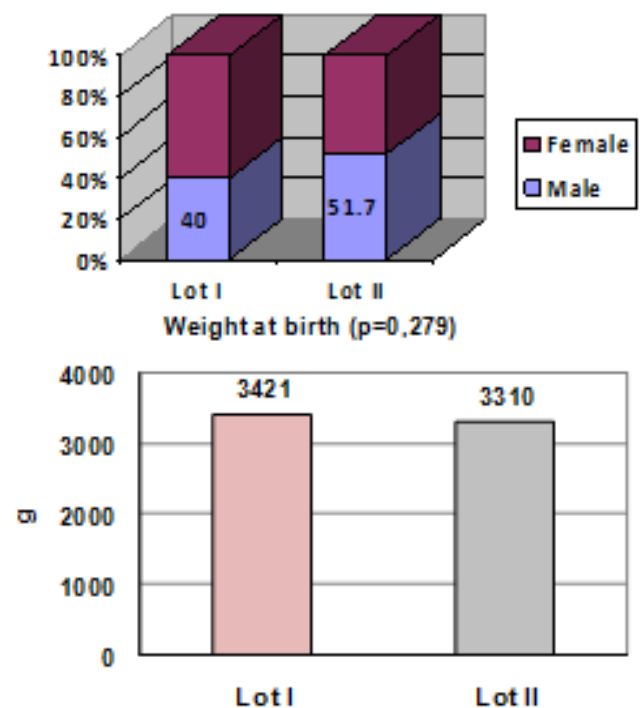

Fig. 1. Gender and weight at birth compared to study lots

For the patients in lot I, $73.3 \%$ of the births were Csections, while in non-at-risk patients the ratio of C-sections was significantly lower (73.3\% vs $51.7 \% ; p=0.045$ ) (fig. 2).

The Apgar score at 1 min ranged from 6 to 9 in patients in the group at-risk, but the mean did not differ significantly from the control group ( 8.61 vs $8.52 ; p=0.908$ ) (fig. 2 ).

Type of birth $(p=0,045)$
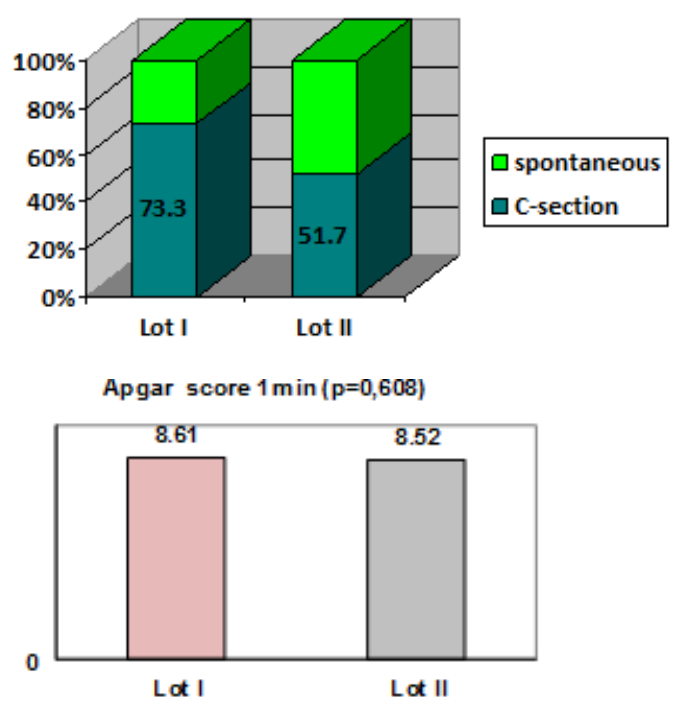

Fig. 2. Birth compared on study lots

Table 1

DESCRIPTIVE STATISTICAL INDICATORS OF MOTHER'SAGE (YEARS) AND GESTATIONAL AGE (WEEKS) COMPARATIVE ON STUDY LOTS

\begin{tabular}{|c|c|c|c|c|c|c|c|c|c|}
\hline \multirow{2}{*}{ Lot } & \multirow{2}{*}{$\mathrm{N}$} & \multirow{2}{*}{ Mean } & \multirow{2}{*}{$\begin{array}{c}\text { Std. } \\
\text { Deviation }\end{array}$} & \multirow{2}{*}{$\begin{array}{l}\text { Std. } \\
\text { Error }\end{array}$} & \multicolumn{2}{|c|}{ Confidence interval } & \multirow{2}{*}{ Min } & \multirow{2}{*}{ Max } & \multirow{2}{*}{$\begin{array}{c}\mathrm{p} \\
\mathrm{F}_{\text {ANova }} \\
\text { test }\end{array}$} \\
\hline & & & & & $-95 \% \mathrm{CI}$ & $+95 \% \mathrm{CI}$ & & & \\
\hline \multicolumn{10}{|c|}{ Mother's age } \\
\hline Lot I & 30 & 25.87 & 4.52 & 0.83 & 24.18 & 27.56 & 19 & 39 & \multirow{3}{*}{0.113} \\
\hline Lot 2 & 60 & 27.60 & 5.00 & 0.65 & 26.31 & 28.90 & 18 & 38 & \\
\hline Total & 90 & 27.03 & 4.89 & 0.52 & 26.00 & 28.05 & 18 & 39 & \\
\hline \multicolumn{10}{|c|}{ Gestational age } \\
\hline Lot I & 30 & 38.43 & 0.82 & 0.15 & 38.13 & 38.74 & 37 & 40 & \multirow{3}{*}{0.309} \\
\hline Lot 2 & 60 & 38.65 & 1.01 & 0.13 & 38.39 & 38.91 & 37 & 42 & \\
\hline Total & 90 & 38.58 & 0.95 & 0.10 & 38.38 & 38.78 & 37 & 42 & \\
\hline
\end{tabular}


Cerebral saturation $\left(\mathrm{rSO}_{2}\right)$

Group characteristics according to cerebral saturation at 1 min:

- rSO varied from 15 to $81 \mathrm{~mL} / 100 \mathrm{~g} / 1 \mathrm{~min}, 76.7 \%$ of the values being below the reference limit $(50 \mathrm{~mL} / 100 \mathrm{~g} / 1 \mathrm{~min})$;

- the mean value $(31.50 \mathrm{~mL} / 100 \mathrm{~g} / \mathrm{min})$ that is very close to the mean cerebral saturation of the group and the result of the Skewness test below $2(p=0.249)$ suggest the fact that the series of cerebral saturation values at 1 min was homogeneous, so significance tests for continuous variables can be applied;

- the mean of the group at-risk was significantly lower $30.47 \pm 15.79 \mathrm{~mL} / 100 \mathrm{~g} / 1 \mathrm{~min}$ compared to the control group $37.61 \pm 15.82 \mathrm{~mL} / 100 \mathrm{~g} / \mathrm{min}(p=0.05)$.

It should be noted that in newborns from alcohol and / or drug-consuming mothers, mean cerebral saturation has shifted from $30.47 \mathrm{~mL} / 100 \mathrm{~g} / 1 \mathrm{~min}$ to $76.71 \mathrm{~mL} / 100 \mathrm{~g} / 10$ min (table 2).

In neonates from mothers at risk, the under-reference level of brain saturation at 1 min, combined with a lower gestational age and the $62.5 \%$ probability of performing a caesarean section at low levels of cerebral saturation was noted in $66.7 \%$ of the cases.

By drawing the ROC curve itwas shown that the cerebral saturation level of 1 minute (AUC $=0.625$; IC $95 \%$ : 0.506 $0.743 ; p=0.043$ ) entered significantly in the caesarean determinism, which is not observed even at 5-10 min (fig. 3).

Neonatal cerebral oxygen saturation ( $\mathrm{rSO}_{2}$ cerebral) increases during the transition period from intrauterine to extra uterine life, with stabilization at normal in the first 10 $\min$ of life $[17=20]$.

Peripheral saturation $\left(\mathrm{SpO}_{2}\right)$.

Group characteristics based on peripheral saturation at $1 \mathrm{~min}:$

- $\mathrm{SpO}_{2}$ varied from 14 to $98 \mathrm{~mL} / 100 \mathrm{~g} / 1 \mathrm{~min}$;
- The mean value $(70 \mathrm{ml} / 100 \mathrm{~g} / \mathrm{min})$ close to the mean peripheral saturation of the group and Skewness test result over $-2(p=-0.597)$ suggest that the set of values for peripheral saturation at 1 min was homogenous, so significance tests for continuous variables can be applied; the mean of the exposed group did not differ significantly from the control group $60.37 \pm 15.07 \mathrm{~mL} / 100 \mathrm{~g} / 1 \mathrm{~min}$ vs $65.35 \pm 13.26 \mathrm{~mL} / 100 \mathrm{~g} / 1 \mathrm{~min}(p=0.112)$.

Note that the average peripheral saturation has shifted from a level of $65.97 \mathrm{~mL} / 100 \mathrm{~g} / 1 \mathrm{~min}$ to $94.74 \mathrm{~mL} / 100 \mathrm{~g} / 10$ min (table III).

In the group at-risk, the cut-off value of $\mathrm{SpO}_{2}$ was set at $70 \mathrm{~mL} / 100 \mathrm{~g} / 1 \mathrm{~min}$ by reading the ROC curve coordinates, with a sensitivity of $50.9 \%$ and a specificity of $51.3 \%$, but the prediction was not statistically significant (AUC = 0.476) (fig. 4).

The average base excess was slightly lower in newborns with the extraction fraction below the cut off value $(-4.64$ vs $-4.18 ; p=0.560)$.

Based on the cases studied, 1 min after birth $23.3 \%$ of the newborns showed an increased level of $\mathrm{pCO}_{2}$ associated with a lower level of peripheral saturation ( $\mathrm{r}=-$ $0.231 ; p=0.05$ ).

The correlation between the level of $\mathrm{pO}_{2}$ and cerebral saturation, recorded $1 \mathrm{~min}$ after birth, was direct, but reduced as intensity $(r=+0.295 ; p=0.049)$. About $27 \%$ of the newborns showed increased values of $\mathrm{pO}_{2}$ that were associated with reduced values in the extraction fraction $(r=-0.272 ; p=0.047)$.

The newborns with an extraction fraction over the cut offhad a more frequent level of $\mathrm{COHb}$ below $1 \%(p=0.756)$ (fig. 5).

Cesarean delivery (probably without labor) has a significant role in the determinism of fetal brain oxygenation with the increase in oxidative metabolism at this level. The lack of the labor process avoids the activation of the cerebral circulatory mechanisms preparatory to the

\begin{tabular}{|l|r|r|r|r|}
\hline rSO2 & & $1 \mathrm{~min}$ & $5 \mathrm{~min}$ & $10 \mathrm{~min}$ \\
\hline $\mathrm{N}$ & & 30 & 30 & 30 \\
\hline Mean & & 30.47 & 63.32 & 76.71 \\
\hline Median & 31.50 & 65.00 & 77.00 \\
\hline Standard Deviation & 15.79 & 14.03 & 7.33 \\
\hline Variance & & 43.43 & 22.16 & 9.56 \\
\hline Skewness Test & & 0.249 & 0.689 & 0.349 \\
\hline Skewness Test Error & & 0.251 & 0.247 & 0.249 \\
\hline Minimum & & 15 & 19 & 60 \\
\hline Maximum & & 81 & 95 & 91 \\
\hline Percentile & 10 & 15.00 & 42.60 & 65.50 \\
& 25 & 24.00 & 56.00 & 70.75 \\
& 50 & 35.50 & 65.00 & 77.00 \\
& 75 & 45.00 & 72.00 & 82.00 \\
\hline & 90 & 58.80 & 80.00 & 85.50 \\
\hline
\end{tabular}

Table 2

STATISTICAL INDICATORS OF CEREBRAL SATURATION IN LOT I ( $\mathrm{mL} / 100 \mathrm{~g} / \mathrm{min})$

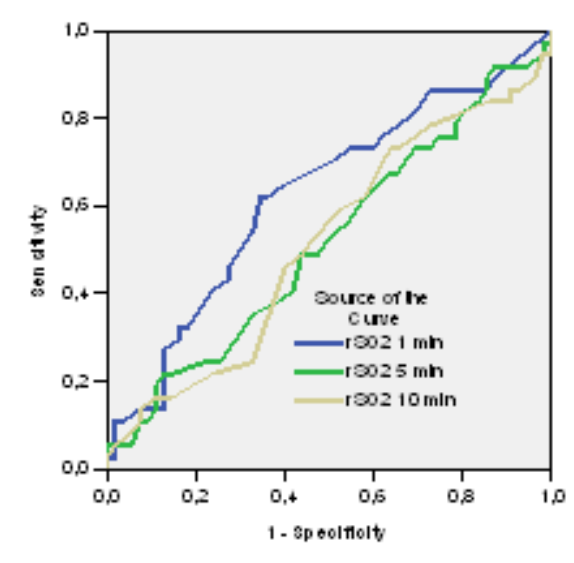

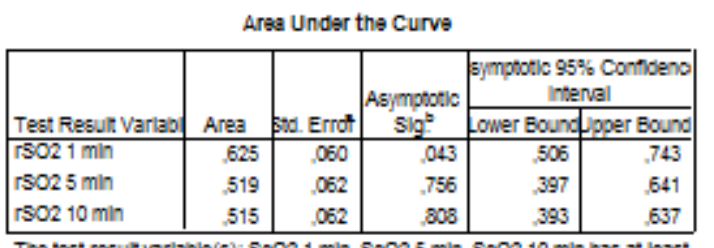

The test result varlable(s): $50021 \mathrm{mln}, 50025 \mathrm{mln}, 500210 \mathrm{mln}$ nas at least posthe actual state group and the negathe achual state group. Statlstics may $\mathrm{t}$ a. Under the nonparametric assumption

b. Null myponesis: true area -0.5

http://www.revistadechimie.ro
Fig. 3. ROC Curve - cerebral saturation in cesarean determinism 


\begin{tabular}{|l|r|r|r|r|}
\hline SpO2 & & $1 \mathrm{~min}$ & $5 \mathrm{~min}$ & $10 \mathrm{~min}$ \\
\hline $\mathrm{N}$ & & 30 & 30 & 30 \\
\hline Mean & 65.35 & 82.57 & 94.74 \\
\hline Median & 70.00 & 83.00 & 95.50 \\
\hline Standard Deviation & 13.26 & 8.38 & 4.18 \\
\hline Variance & 20.67 & 10.15 & 4.41 \\
\hline Skewness Test & -0.597 & -0.217 & -1.999 \\
\hline Skewness Test Error & 0.247 & 0.247 & 0.249 \\
\hline Minim & & 14 & 63 & 74 \\
\hline Maxim & & 98 & 100 & 100 \\
\hline Percentile & & 48 & 70 & 89 \\
& 25 & 56 & 77 & 94 \\
& 50 & 70 & 83 & 96 \\
& 75 & 75 & 89 & 97 \\
\hline & 90 & 80 & 93 & 98 \\
\hline
\end{tabular}

Table 3

STATISTICAL INDICATORS OF PERIPHERAL SATURATION IN LOTI $(\mathrm{mL} / 100 \mathrm{~g} / \mathrm{min})$

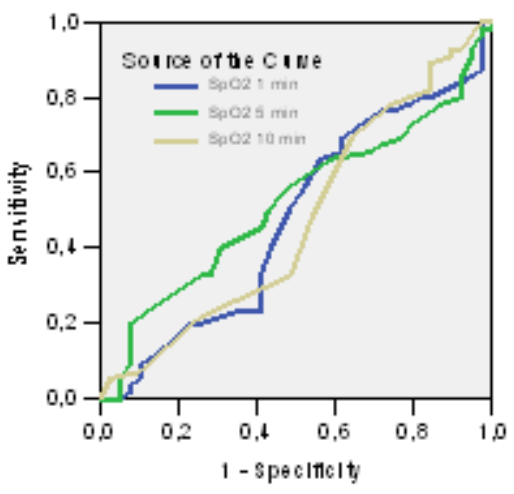

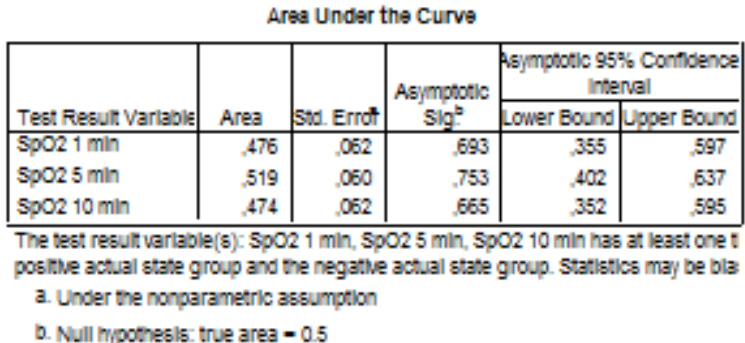

Fig. 4. ROC Curveperipheral saturation in determining $\mathrm{C}$-sections

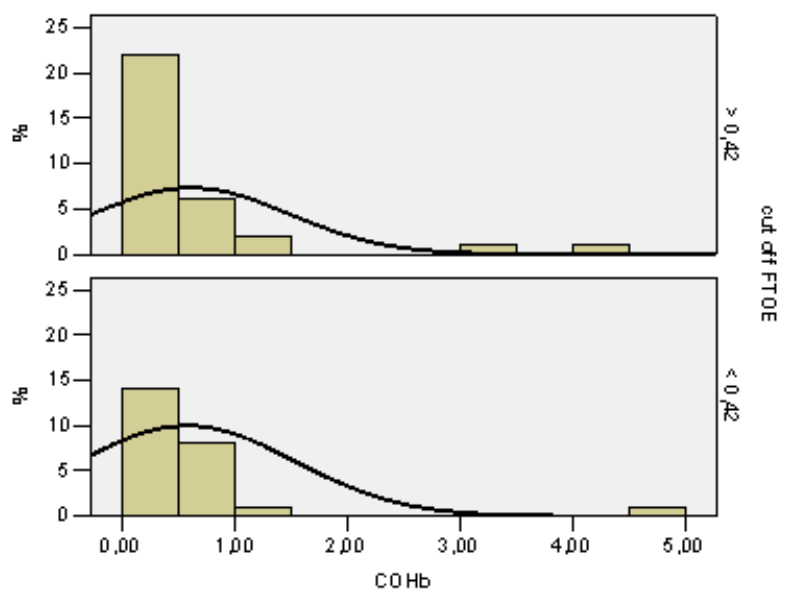

Fig. 5. Percentage differences depending on the level of $\mathrm{COHb}$ and the cut off value of the extraction fraction for lot I

physiological transient hypoxic moment of birth, thus, at the time of extraction, the only adaptive fetal mechanism to hypoxia is that at the level of the brain tissue by increasing the extraction of oxygen [15].

The fraction of tissue oxygen extraction (FTOE) at neonatal brain level has a postnatal progression, with stabilization at normal values in the first 10 minutes of life [16-20].

\section{Conclusions}

The age of the mothers accepted in the study ranged from 18 to 39 years, recording a slightly lower mean age in alcohol and / or drug-consuming patients.

Gestational age ranged from 37 to 42 weeks, with no significant difference in the mean (about 38 w eeks) when related to alcohol or alcohol consumption.

In alcohol-consuming mothers, the gender of the newborn was more frequently male.
Weight at birth was normal in both study groups.

Newborns born to mothers who have consumed alcohol and / or drugs, including during pregnancy, have lower levels of cerebral saturation and peripheral saturation 1 minute after birth.

In $16.7 \%$ of newborns, the 1 minute extraction limit was below the reference limit.

\section{References}

1.MELLOS, E., LIAPPAS, I., PAPARRIGOPOULUS, T., International Journal of Experimental and Clinical Pathophysiology and Drug Research, 24, 2010, p. 761.

2.LAU, C., AMBALAVANAN, N., CHAKRABORTY, H., WINGATE, M.S., CARLO, W.A. Pediatrics, 131, no. 5, 2013, p. 855.

3.FANAROFF, A.A., HACK, M., WALSH M.C., Semin Perinatol, 27, no. 4, 2003, p. 281.

4.UNTU, I., CHIRITA, R., BULGARU, I. D., CHIRILA, D. B., CIUBARA, A., BURLEA, S. L., Revista De Cercetare Si Interventie Sociala, 48, no. 48, 2015, p. 216.

5.HERON, M., SUTTON, P.D., XU, J., VENTURA, S.J., STROBINO, D.M., GUYER, B. Pediatrics, 125, no. 1, p. 4.

6.SCRIPCARU, V., IOV, T., KNIELING, A., DAVID, S.M., RADU, C.C., Rom J Leg Med, 26, no. 2, 2018, p. 206.

7.DAMIAN, S.I., NEDELEA, P., DAVID, S., KNIELING, A., MOLDOVEANU, S., SANDU, I., IOV, C.J ., Rev. Chim.(Bucharest), 68, no. 11, 2017, p. 2650.

8.RADU, C., BULGARU Iliescu, D., RAHOTA, D., DUMBRAVA, D.P., Revista Romana De Bioetica, 12. no. 2, 2014, p. 53.

9.*** American Academy of Pediatrics and The American College of Obstetricians and Gynecologists: Guidelines for Perinatal Care. 5th Ed Elk Grove Village and Washington DC, AAP and ACOG 2002; 199201, 378-379.

10.PERJU DUMBRAVA, D., RADU, C.C., DAVID, S., IOV, T., IOV, C.J ., SANDU, I., BULGARU ILIESCU, D., Rev. Chim.(Bucharest), 69, no. 9, 2018, p. 2407.

11.HAMILTON, B.E., MARTIN, J.A., VENTURA, S.J ., National Vital Statistics Report, 61, no. 5, 2012, p. 1. 
12.WILSON-COSTELLO, D., FRIEDMAN, H., MINICH, N., SINER, B., TAYLOR, G., SCHLUCHTER, M., HACK, M. Pediatrics, 119, no. 1, 2007, p. 37.

13.HINTZ, S.R., KENDRICK, D.E., VOHR, B.R., POOLE, W.K., HIGGINS. R.D., Pediatrics, 115, no. 6, 2005, p. 1645.

14.PERJU DUMBRAVA, D., RADU, C.C., IOV, T., DAMIAN, S.I, SANDU, I., TIMOFTE, D., CHIROBAN, O., Rev. Chim.(Bucharest), 69, no. 7, 2018, p. 1889.

15.NASTASE, L., STOICESCU, S.M., BANCEANU, G., Cerebral regional oxygen saturation of the neonate during the transition to extrauterine life. Obstetrics and Gynecology, LXV, 2017, p. 235.
16.0MO-AGHOJ A L. Ann Med Health Sci Res., 4, no. 1, 2014, p. 8. 17.VOHR, B.R., MSALL, M.E. Semin Perinatol. 21, no. 3, 1997, p. 202. 18.VOHR, B.R., WRIGHT, L.L., POOLE, W.K., MCDONALD, S.A. Pediatrics, 116, no. 3, 2005, p. 635.

19.STEPHENS, B.E., VOHR, B.R., Pediatric Clinics of North America, 56, no. 3, 2009, p. 631.

20.MANDY, G.T. (2012). Long term complications of the premature infants. in: Kim MS, Weisman LE, (eds)

$\overline{\text { Manuscript received: } 21.03 .2018}$ 